Şiir Kilkiş $^{1} \quad$ JEL: 032

DOI: 10.5937/industrija42-5084

UDK: 005.53:620.9(560) ;

502.171:620.9

Original Scientific Paper

\title{
Motors of Change Framework for R\&D and Innovation Planning towards Sustainable Energy in Turkey ${ }^{2}$
}

\author{
Article history: \\ Received: 16 November 2013 \\ Sent for revision: 12 December 2013 \\ Received in revised form: 14 January 2014 \\ Accepted: 24 January 2014 \\ Available online: 28 March 2014
}

\begin{abstract}
In light of the challenge of decoupling economic growth from environmental pressure, there is a revival of mission-oriented R\&D and innovation programs in prioritized areas. However, it remains unclear how topdown and bottom-up approaches should be integrated to effectively achieve this urgent aim. This governance issue is addressed in this paper with a novel framework that builds upon the transition management literature. This framework uses the "motors of change" concept in a futuristic view to plan the governance process behind the National Energy R\&D and Innovation Strategy (2011-2016). A total of six different participatory approaches across the stages of strategy-building, prioritization, and implementation were designed to integrate top-down and bottom-up approaches to manage a missionoriented approach and activate the suitable motor of change in the energy sector in Turkey. The design of the governance process was empirically implemented and validated in a process that led to the launch of eleven energy calls in the first year of the Strategy. The paper concludes with the key role of targeted participatory approaches in the launch of the Science and Technology Push Motor to transform the R\&D and innovation landscape towards sustainable energy in Turkey.
\end{abstract}

Keywords: $R \& D$, innovation, energy, governance, sustainable development

\footnotetext{
${ }^{1}$ The Scientific and Technological Research Council of Turkey (TÜBITAK), siir@kth.se 2 This paper is developed from an original manuscript that was presented at the $7^{\text {th }}$ Conference on Sustainable Development of Energy, Water and Environment Systems that was held in Ohrid, Macedonia between July 1-7, 2012, and the expertise thesis of the author that was prepared and presented at TÜBITAK.
} 
Kilkiş S.: Motors of Change Framework for R\&D and Innovation Planning towards...

\title{
Okvir motora promene za planiranje istraživanja, razvoja i inovacija ka održivoj energiji u Turskoj
}

\begin{abstract}
Apstrakt: U svetlu izazova razdvajanja ekonomskog rasta od pritiska na životnu sredinu, oživeli su programi orijentisani na misiju istraživanja, razvoja $i$ inovacija u priritetnim oblastima. Međutim, još uvek je nejasno kako treba integrisati pristupe top-down i bottom-up kako bi se efektivno postigli ovi hitni ciljevi. Rad se ovim pitanjem bavi uz pomoć novog okvira koji se oslanja na literaturu o upravljanju tranzicijom. Ovaj okvir koristi koncept "motora promene" sa futurističkim ciljem planiraja procesa koji stoji iza Strategije istraživanja, razvoja i inovacije nacionalnih energetskih resursa (2011-2016). Dizajnirano je ukupno šest različitih participativnih pristupa kroz faze izgradnje, prioritizacije i primene strategije kako bi se integrisali pristupi topdown i bottom-up u cilju upravljanja pristupom koji je orijentisan na misiju i aktiviranja odgovarajućih motora promene u energetskom sektoru Turske. Dizajn procesa upravljanja je empirijski implementiran i potvrđen u procesu koji je doveo do pokretanja jedanaest energetskih tendera u prvoj godini primene Strategije. Rad se završava zaključkom da ključnu ulogu u pokretanju motora na polju nauke i tehnologijer igraju ciljani participativni pristupi sa ciljem transformisanja opšte situacije istraživanja, razvoja $i$ inovacija ka održivoj energiji u Turskoj.
\end{abstract}

Ključne reči: Istraživanje i razvoj, inovacija, energija, upravljanje, održivi razvoj

\section{Introduction}

Decoupling economic growth from environmental pressures is one of the grand challenges of the $21^{\text {st }}$ century (Stamm et al., 2009; Soete, 2010). A key asset in the pursuit of sustainable development is research, development $(R \& D)$, and innovation. Such activities have a role in stimulating the speed of economic growth and in directing it to have much less of an impact on natural resources. In light of the sustainability challenge, the focal point of innovation systems has started to shift away from purely economic aims, i.e. increasing gross domestic product. Instead, the focus has moved towards an integrated view for sustainable development, i.e. also reducing environmental pressures.

This "dual-duty" for R\&D and innovation policy has necessitated the revival of mission-oriented programs. Once prominent in the field of security and aerospace in the 1950's and 1960's, including the Apollo Program for "landing a man on the moon and returning him safely to Earth," mission-oriented R\&D programs are now required in "newer" areas of priority. These include the field of energy and environmental technologies. When grouped together as "clean 
Kilkiş S.: Motors of Change Framework for R\&D and Innovation Planning towards...

technologies," the field of energy and environmental technologies are indicated as the sixth Kondratieff long wave of innovation (Hargroves, 2006).

Mission-oriented approaches in newer areas are seen to differ from those of past areas in at least three main ways. While it is known that the space program led to the commercialization of a total of about 1,400 technologies (Dick, 2007; NASA, 2009), clean technologies have the potential to alter the most fundamental production and consumption patterns in an economy. Due to this more radical and "pervasive" character, mission-oriented approaches in newer areas are seen to require even a more systemic policy approach.

In addition, there is a wider range of actors, the need to diffuse the results is broader, and there is a role for both radical and incremental innovation (Freeman, 1996). Horizontal, more cross-cutting areas, such as sustainable development, also require a greater sense of multi-actor cooperation across government and stakeholders (Stine, 2008). Therefore, "newer" missionoriented approaches to take better care of the Earth may be even more challenging than sending a man out of the Earth and back (Morlacchi, 2009).

\section{Figure 1. Kondratieff Long Waves of Innovation}

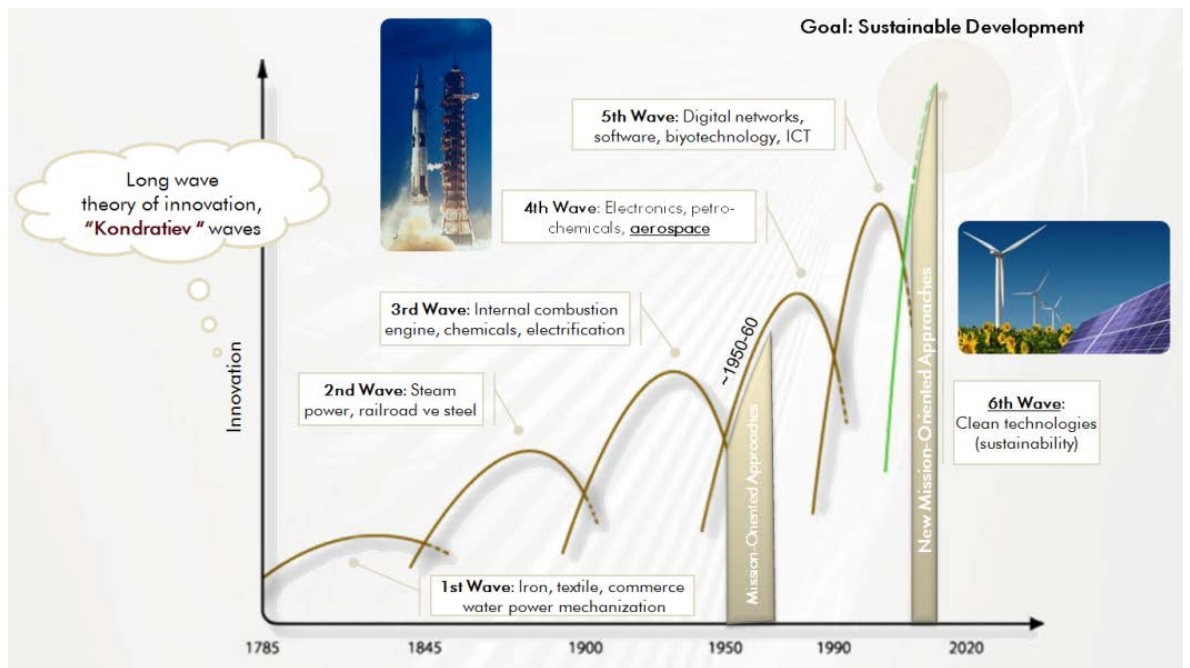

Source: (Re-arranged based on Hargroves et al. (2006); Stamm et al. (2009) and Freeman (1996))

This paper describes a governance process that combined both bottom-up and top-down approaches in activating motors of change in Turkey in the field of energy. The paper maps the phases of the related governance process in the development of the "National Energy R\&D and Innovation Strategy," which 
Kilkiş S.: Motors of Change Framework for R\&D and Innovation Planning towards...

was coordinated by the Scientific and Technological Research Council of Turkey (TÜBITAK). The paper is organized into three main sections. The first section maps out phases of the governance process, which indicates the participatory approaches and defines how the Strategy came into being. The second section describes the strategic framework of the Strategy, the main grant mechanisms for mission-oriented R\&D projects, and the first calls in the energy sector. The third section highlights expected outcomes for "motors of change" towards sustainable energy and key targets for the future. The paper concludes with the vitality of R\&D and innovation for sustainable energy.

\section{Methodology of Research}

In contrast to a top-down approach by the government, the governance process (Kooiman, 1993) requires a greater sense of interaction with a diversity of societal actors while avoiding a lack of direction in policy making. Especially for sustainable development, governance requires the coordination of multiple agents to facilitate the managing or "steering" of existing trends towards more desirable states (Loorbach, 2007; Rotmans et al., 2000). As a result, a "transition management" framework has been put forth as a multiactor process in which individuals and representatives from government, knowledge institutes, businesses, and intermediaries participate in the process of shaping a more sustainable future. A distinguishing factor is a "plurifocal" viewpoint that links the future and the present (Loorbach, 2007).

In light of the challenge of governance for sustainable development, the question of how top-down and bottom-up approaches should be integrated still remains to be fully answered. This forms the basis of the central research question of this paper. In addition, the paper seeks to integrate novel concepts from the innovation literature, such as "transition management" and "motors of change" in the process of developing a national strategy to activate the R\&D and innovation system in the area of energy technologies in Turkey.

"Motors of change" is a term that was first coined by Hekkert et al. (2007) and classified into four types of motors for sustainable innovation by Suurs (2009). These "motors" are defined by the different patterns of interaction among the main activities or functions in the processes that are able to provide impetus to R\&D and innovation activities. As a result, these motors are found to be useful in defining the different kinds of "mission-oriented" approaches that may be possible for a given field. The first of these motors is the "Science and Technology Push Motor" in which positive expectations and/or research outcomes trigger the setting up of government-supported R\&D programs. For this motor to be activated successfully, rather than a single-time event, there must be an ongoing "cycle" of interactions between all related dynamics. 
Kilkiş S.: Motors of Change Framework for R\&D and Innovation Planning towards...

Consequently, financial resources need to be allocated according to priorities and the innovation actors need to engage in a satisfactory level of knowledge development and diffusion activities. At the same time, these activities must provide feedback to the program so that the motor is able to advance "ontrack" in the right direction. All of this must take place with minimum level of "system failures," which can prohibit the development of the motor itself. This is especially valid for clean technologies, which can be faced with a more intense set of transition and governance failures. Thus, the programs need to be designed in a way that foresee the potential problems more proactively and embed the needed measures directly within the various calls, such as stimulation of multi-discipline and multi-sectoral collaboration (Kılkış, 2012).

Table 1. Synthesis of the Literature Based on the Role of the Functional Dynamics in the Four Phases of the Motors of Change

\begin{tabular}{|c|c|c|c|c|c|c|c|}
\hline \multirow[t]{2}{*}{ Motor } & \multirow[t]{2}{*}{ Motor Description } & \multicolumn{6}{|c|}{ Functional Dynamics } \\
\hline & & 남 & $\mathbb{\sim}$ & $\ddot{\sim}$ & $\underset{\amalg}{\sim}$ & $\stackrel{\llcorner}{\longrightarrow}$ & $\stackrel{\bullet}{\Perp}$ \\
\hline $\begin{array}{l}\text { Science and } \\
\text { Technology Push } \\
\text { Motor (M1) }\end{array}$ & $\begin{array}{l}\text { The motor is driven by F4 and } \\
\text { F6 with required feedback } \\
\text { from F2 and F3. F1 may be } \\
\text { weakly present but not } \\
\text { essential. }\end{array}$ & $W$ & $P$ & $P$ & $T$ & $N$ & $T$ \\
\hline $\begin{array}{l}\text { Entrepreneurship } \\
\text { Driven Motor (M2) }\end{array}$ & $\begin{array}{l}\text { M2 gains activation from F1 } \\
\text { as the trigger with support } \\
\text { from F2, F3, F4, and F6. F5 } \\
\text { may still be weakly present. }\end{array}$ & $T$ & $P$ & $P$ & $P$ & $W$ & $P$ \\
\hline $\begin{array}{l}\text { System Building } \\
\text { Motor (M3) }\end{array}$ & $\begin{array}{l}\text { The coupled working of F1 } \\
\text { and F3 are the main drivers of } \\
\text { this motor. All functions are } \\
\text { fully present and developed. }\end{array}$ & $T$ & $P$ & $T$ & $P$ & $P$ & $P$ \\
\hline $\begin{array}{l}\text { Market-Driven } \\
\text { Motor (M4) }\end{array}$ & $\begin{array}{l}\text { The system is now fully } \\
\text { mature and driven by F5. }\end{array}$ & $P$ & $P$ & $P$ & $P$ & $T$ & $P$ \\
\hline \multicolumn{8}{|c|}{$\begin{array}{l}\text { * F1 - Facilitation of experimentation and learning (entrepreneurship); F2 - Knowledge } \\
\text { development; F3 - Knowledge diffusion; F4 - Guidance of search and selection (priority } \\
\text { topic calls etc.); F5 - Market formation; F6 - Development and mobilization of } \\
\text { resources (includes human resources, financial resources, and research } \\
\text { infrastructure). }\end{array}$} \\
\hline
\end{tabular}

Source:Author

Table 1 provides the four phases of the motors of change (Suurs, 2009) and identifies them by their characteristic patterns. These patterns are expressed by the roles that the different six main possible activities in innovation systems may take. The six main activities or "functional dynamics" were introduced as 
Kilkiş S.: Motors of Change Framework for R\&D and Innovation Planning towards...

the "functional dynamics" approach by Bergek et al. (2008) and Hekkert et al. (2007). The six functional dynamics are provided as the footnote to Table 1. Based on an original synthesis of the related literature, the functional dynamics are expressed in Table 1 with marks of $T$ when the function is the driving force (trigger) of the motor, $P$ when the function is present with direct feedback from other functions, $W$ when weakly present (limited feedback from other functions), and $N$ when the function is very weak and/or non-existent.

The evolution of the different roles that the functions take from motor to motor is apparent from Table 1. The phase from which to start the activation process depends on the level of maturity and the existing functional interactions within the system. If the motors of change are put into the context of an S-curve that is frequently used in innovation policy, then the third motor (system building motor) corresponds to the stage of "take-off" or rapid progress (Suurs, 2009).

In accordance with the research aim, a unique methodology to test the research question was developed. An integrated process with both top-down and bottom-up elements was designed. As shown in Table 2, this process has three main phases to manage a mission-oriented approach to activate "motors of change" in the energy sector in Turkey, namely strategy building, prioritization, and implementation. The approaches are designed to lead to the development and implementation of the National Energy R\&D and Innovation Strategy in Turkey. The types of the approaches are classified by the letter $A$ for purely bottom-up approaches and the letter $B$ for those approaches that contain a more top-down approach integrated with bottom-up feedback.

Table 2. Methodology to Activate the S\&T Push Motor in the Field of Energy in Turkey Integrating Bottom-Up and Top-Down Approaches

\begin{tabular}{|c|c|c|c|c|c|c|c|c|}
\hline \multirow[t]{2}{*}{ Phase } & \multirow[t]{2}{*}{ Type } & \multirow[t]{2}{*}{ Approach } & \multicolumn{6}{|c|}{ Functional Dynamics } \\
\hline & & & $\overrightarrow{-}$ & $\mathbb{N}$ & $\tilde{\Psi}$ & $\underset{\square}{\square}$ & $\stackrel{\sim}{\square}$ & 인 \\
\hline \multirow{4}{*}{$\begin{array}{l}\text { Strategy- } \\
\text { Building }\end{array}$} & $A$ & Stakeholder Workshop & $\checkmark$ & $\checkmark$ & $\sqrt{ }$ & $\checkmark$ & $\checkmark$ & $\checkmark$ \\
\hline & $B$ & Working Group Meetings & & $\checkmark$ & $\sqrt{ }$ & $\checkmark$ & & $\checkmark$ \\
\hline & $A$ & Focus Groups' Meeting & & $\checkmark$ & $\checkmark$ & $\checkmark$ & & $\checkmark$ \\
\hline & $B$ & Final Consultation Meetings & & $\checkmark$ & $\checkmark$ & $\checkmark$ & & $\checkmark$ \\
\hline \multirow[t]{2}{*}{ Prioritization } & $A$ & Focus Groups' Meeting cont. & & & & $\checkmark$ & & \\
\hline & $B$ & $\begin{array}{l}\text { High-Level Prioritization } \\
\text { Meeting }\end{array}$ & & & & $\checkmark$ & & \\
\hline Implementation & $B$ & $\begin{array}{l}\text { Call Programs Consultation } \\
\text { Committees }\end{array}$ & & $\checkmark$ & $\checkmark$ & $\checkmark$ & & $\checkmark$ \\
\hline
\end{tabular}

Source:Author 
Kilkiş S.: Motors of Change Framework for R\&D and Innovation Planning towards...

The participatory approach that is provided in Table 2 is designed and tested with conceptual support from the motors of change literature. The same table pairs the approaches with the functional dynamics they involve. The scientific contribution of this research may be summarized to be two-fold. First, the motors of change literature mainly focused on retrospective studies to identify the functional patterns (Suurs, 2009). This research has made a scientific contribution to apply the motors of change with a futuristic perspective to activate motors of change in Turkey. Second, an integrated process is designed to activate the functional dynamics that have a key role in the first motor of change. This is the functional dynamic of "guidance of search and selection" (F4) that depends on prioritization. By design, the motor of change is to be activated when this function is coupled with the mobilization of human and financial resources (F6) in the form of researchers and call-based funding to feed knowledge development (F2) and knowledge diffusion (F3).

\section{Data and Discussion}

Figure 2 summarizes the characteristics of the process that led to the implementation of the National Energy R\&D and Innovation Strategy in Turkey. This process is based on several layers of participatory approaches ranging from workshops to other interactive mediums, including high-level meetings. The common point of these approaches is that each one has been structured to involve a broad range of stakeholders in the energy field. Each approach builds on the outputs of the previous one in a "cascaded" manner based on evolving tasks that serve different phases of the governance process. Hence, it is possible to integrate bottom-up and top-down elements.

In Figure 2, the participatory approaches are organized according to the main phase to which they contributed in the governance process. These phases are classified as strategy-building, prioritization, and implementation phases (see top of figure). These fit well with the "strategic, tactical and operational" phases that are identified for transition management (Loorbach, 2007).

While these phases appear in a seemingly "linear" manner, it is apparent that they involve non-linear processes. The flowchart that follows below each phase indicates that the process as a whole involved several parallel steps with more complex feedbacks. The shapes of the steps further characterize how a specific step serves the particular phase of the governance process. A step may involve preparatory inputs, various processing activities, or final tasks and/or decision-making points (diamond shape). At the same time, a given participatory body may have more than one role that serves these phases. On a time scale, the left-side of Figure 2 marks $t_{0}$ as the beginning state and $t_{p}$ as the end-state. In addition to overall coordination, qualitative and quantitative analyses (light colored shape) were conducted by TÜBITAK. 
Kilkiş S.: Motors of Change Framework for R\&D and Innovation Planning towards...

Figure 2. Phases of the Governance Process Leading to the Implementation of the National Energy R\&D and Innovation Strategy

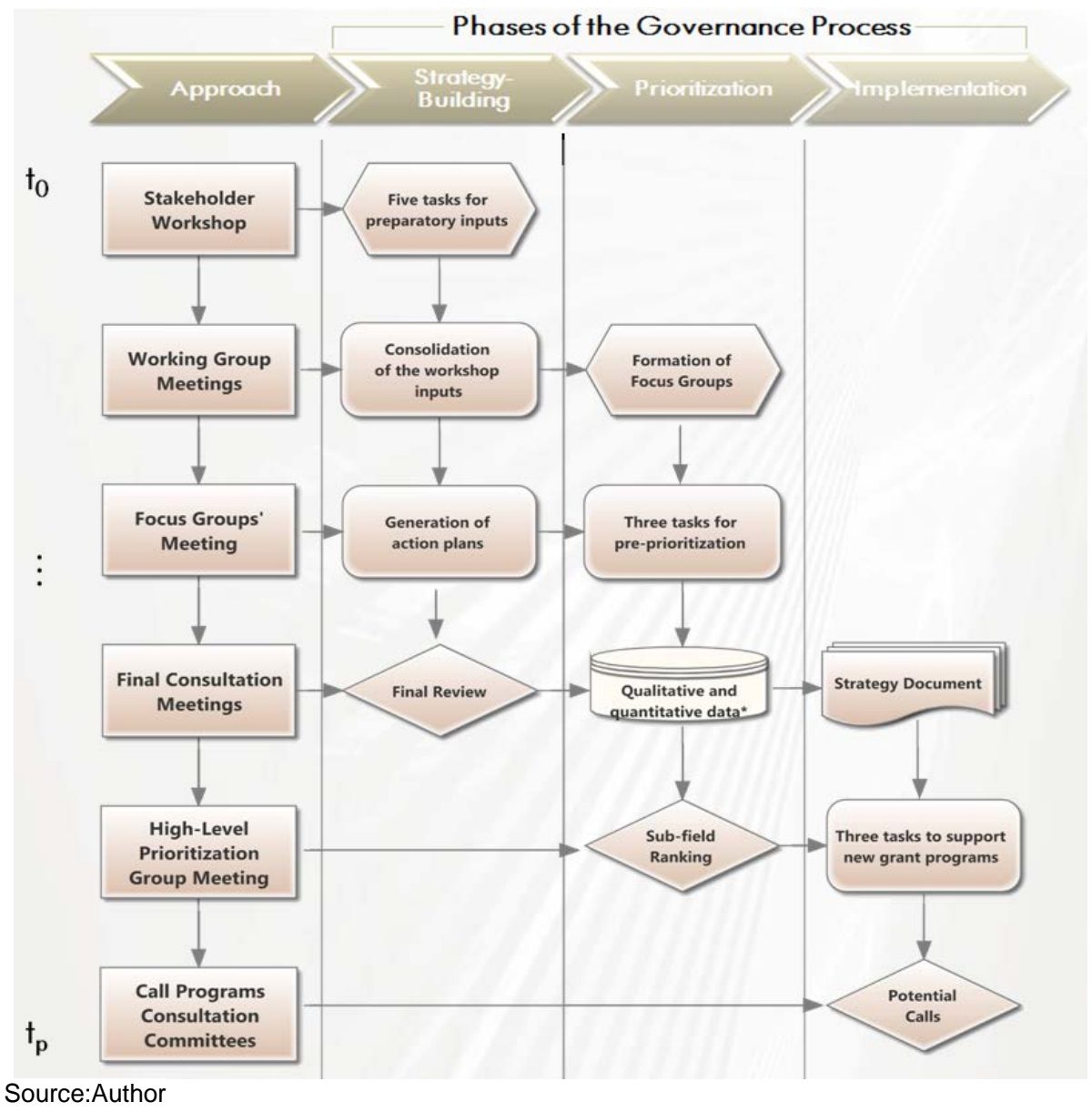

\subsection{The Strategy-Building Phase}

Stakeholder Workshop: The array of participatory approaches was launched with the Stakeholder Workshop. This workshop brought together a total of 59 different stakeholders from the energy field (SCST, 2010). These involved academicians and representatives of private sector firms and governmental bodies with contributions to the energy R\&D and innovation ecosystem. 
Kilkiş S.: Motors of Change Framework for R\&D and Innovation Planning towards...

The workshop was designed with the aim of producing inputs to the Strategy while adopting a more holistic approach to consider the energy R\&D and innovation system as a whole. This was done with a set of "team-oriented" tasks to involve each stakeholder in formulating joint inputs to the Strategy. Prior to the workshop, TÜBITAK prepared a background report to facilitate a more informed participation at the workshop. This included an analysis of the Turkish energy R\&D and innovation ecosystem according to the six dynamics that were introduced in the "functional dynamics" approach (Bergek et al., 2008; Hekkert et al., 2007). It also included a distribution of R\&D funding and research institutes according to energy sub-fields, a comparison of the energy statistics of Turkey, and other "horizon-scanning" activities, including newly emerging trends in the R\&D and innovation strategies of international actors.

With such a background, the workshop participants were asked to realize a total of five tasks. The teams were organized by sector, e.g. private sector etc. During and after the workshop, this arrangement allowed a comparison of inputs according to differing sectoral needs. Participants also had the opportunity to build consensus within their teams based on such techniques as giving points to their team members' ideas and writing joint statements.

The sequencing of the tasks allowed a logical flow towards obtaining key inputs. The participants were asked to identify and discuss potential socioeconomic and environment benefits (Task 1) and the importance of the functional dynamics (Task 2) before making their proposal for the vision statement. Team leaders then came together to consolidate the inputs of the seven teams and to propose a "common" vision statement that can be reached if the R\&D and innovation system is activated in the energy field (Task 3). The principle was to progress while sharing within/between teams.

The workshop proceeded with the tasks that would generate the most vital inputs for the Strategy. This was the identification of problems and bottlenecks considering each dynamic (Task 4), followed by the formulation of potential action plans to solve the most urgent problems (Task 5). In total, the teams generated 64 solutions to what they perceived as the most urgent problems. To the best knowledge of TÜBITAK, this workshop was the first participatory workshop of its kind in which the functional dynamics approach was utilized.

By nature of design, this workshop served the strategy-building phase with preparatory inputs. In Figure 1, this is marked as a "preparation" step.

Working Group Meetings: TÜBITAK's role in coordinating the preparation of the Strategy proceeded with the next participatory approach, i.e. a Working Group. This Group was composed of nine members that enabled a balance between different sectors. As a core group, the Group was tasked with the challenge of consolidating the outputs of the workshop, which became the inputs of this Group for further processing, into a more strategic whole. 
Kilkiş S.: Motors of Change Framework for R\&D and Innovation Planning towards...

To accomplish this task, the Working Group convened five times with ongoing activities between meetings. The meetings focused either on coordination of different policy documents or consolidation of the solution statements from the workshop. The meetings were beneficial for the energy field as a "horizontal" area that requires cross-agency coordination like other areas of importance for sustainable development. At the fourth meeting, the focus was on devising an energy research agenda and forming focus groups to initiate another phase of the governance process. As marked in Figure 2, this represents the first "preparatory step" in the parallel phase of prioritization.

Focus Groups' Meeting: The Focus Groups' Meeting took place with 55 representatives from universities, the private sector, and governmental bodies (TÜBITAK, 2011). The Meeting served two phases of the governance process at the same time, including the strategy-building phase. Regarding this phase only, each of the six focus groups was tasked with the role of developing action plan recommendations. It was expected that these focus groups would generate new action items regarding particular fields of activity within the energy field. These action items were further specified as "short," "medium," and "long-term" based on whether the action could be completed within 2, 2-3 or 3-5 years, as well as the institution that could contribute to the completion of the action. Action item proposals were also collected for the six dynamics.

Final Consultation Meetings: Once the action plan of the Strategy started to take shape, it was ready to be presented to the views of other sectoral stakeholders. Three separate meetings were held to complete the phase of strategy-building. One was held with non-governmental organizations representing the private sector, one with the inter-sectoral Working Group (their fifth meeting), and one with representatives of other governmental bodies. These meetings provided a medium to engage system actors in deliberating their views and discussing the draft Strategy. This approach also provided a "control" mechanism to ensure that the Strategy represented the expectations of a broader set of societal actors in the energy field in Turkey.

As indicated in Figure 2, this approach and its inputs served as an important "decision-point" to check whether the Strategy was sufficient to fulfil its expected purpose. The remaining refinements that were made were also a vital step before the Strategy document was presented to the $23^{\text {rd }}$ meeting of the SCST. ${ }^{3}$ The details of this Strategy are given in the subsequent sections.

\subsection{The Prioritization Phase}

Focus Groups' Meeting: The governance process involved several parallel phases, most notably the phase of "prioritization." The Working Group had

\footnotetext{
${ }^{3}$ The highest decision-making body, the Supreme Council for Science and Technology
} 
Kilkiş S.: Motors of Change Framework for R\&D and Innovation Planning towards...

decided that six focus groups would be formed in the sub-fields of the energy field. The criteria against which the sub-fields would be prioritized were also prepared. Similar to the sub-fields as defined in the International Energy Agency (IEA) R\&D Survey, the six focus groups were oriented towards energy technologies for energy efficiency, conventional energy, renewable energy, energy storage, transmission and distribution, and finally nuclear energy.

The Focus Groups made "qualitative" evaluations for the prioritization phase. In fact, three of the four tasks of the Focus Groups' meeting were centered towards prioritization while the fourth task regarded field-specific action plans.

First, a total of 5 general and 8 energy-specific criteria were given weights (Task 1). The general criteria included contribution to self-sufficiency, the sustainable use of natural resources, socio-economic development, sectoral efficiency, and competitiveness. The energy-specific criteria were increasing security of supply, the usage of local resources, efficient energy production, diffusion of cleaner alternatives, energy conservation, and efficiency distribution. Second, topics were given points against the criteria (Task 2). In addition to those technology activity topics that were included in the first foresight project of Turkey, Vision 2023, participants were invited to add their own topics. Finally, weighted scores per topic were obtained (Task 3).

The results of the Focus Groups were beneficial to obtain an updated, qualitative assessment of the various topics in the energy field. Afterwards, these topics were classified based on the taxonomy of the energy field. This allowed the prioritization of each sub-field to be compared with R\&D spending in the same sub-field for combining qualitative and quantitative inputs.

High-Level Prioritization Meeting: The High-level Prioritization Meeting for Energy was the first of five high-level prioritization meetings that were held on the prioritized sectors of UBTYS 2011-2016 between March and May 2012 (TÜBITAK, 2012-a). The timing of this first meeting was also fitting as the groundwork of two new, call-based grant programs, namely the TÜBITAK 1003 and TÜBITAK 1511 Programs, were completed. This allowed the energy field to capture a synergy between the approved Strategy on the one hand and two new, implementation-ready grant programs of TÜBITAK on the other.

Before the meeting, TÜBITAK shared several studies to provide background analysis. The energy "quadrant" study superimposed key qualitative and quantitative inputs (TÜBITAK, 2011). The vertical axis was designated to be a scale of the total budget of project grants that were given by TÜBITAK. The horizontal axis was designated as the weighted average of the priority score that was given by the Focus Groups. From this analysis, it was possible to position the sub-fields into four "quadrants" to compare present R\&D spending with relative priority scores. It was emphasized that this was a "picture" of the present with bottom-up funding schemes. It was not a picture of what it should 
Kilkiş S.: Motors of Change Framework for R\&D and Innovation Planning towards...

or ought to be in the future. It was up to the meeting participants to reprioritize them considering both R\&D capacity and their level of importance.

The meeting brought together representatives from 23 different institutions of the energy sector. The meeting was moderated to ensure that the session progressed smoothly and covered all of the main tasks. Task 1 concerned a ranking of the top five sub-fields in two parts. In part one, each participant ranked the top five areas according to their personal evaluation. Once the results were tallied, a discussion was provoked by the moderator with an aim of promoting a common set of criteria, including the realities of R\&D capacity, national needs, and the effect on the national trade deficit. After discussions, a second round of scoring was made to obtain more "objective" results.

The top five energy sub-fields came out to be (clean) coal, solar energy, energy efficiency in the built environment, energy efficiency in industry, and hydrogen and fuel cells. In the discussions after the ranking, it was expressed that other sub-fields, which received a somewhat lower ranking, would be necessary to complement the top five sub-fields, such as energy storage for solar energy. As a result, it was decided that cross-linkages between subtopics must be considered when project calls are implemented next.

Task 2 was geared towards generating more inputs for the "implementation" stage of the new, call-based programs of TÜBITAK. The participants were asked to recommend targets for each of the energy sub-fields. In Task 3, participants were asked to identify those sub-fields in which there was a need for developing R\&D capacity by means other than call programs. This task launched a sense of "multi-agency" cooperation in areas such as human resources and research infrastructure to seek complementary mechanisms.

As indicated in Figure 2, the High-Level Prioritization Meeting for Energy served two phases of the governance process at the same time. As a governance mechanism, it was directed to the prioritization of the sub-fields while it further provided key inputs for the following implementation phase.

\subsection{The Implementation Phase}

The Strategy came into effect immediately after being approved at the $23^{\text {rd }}$ meeting of the SCST. Based on this development, the launch of two new callbased programs, which was in the making for about a year, gained speed. While the Prioritization Meeting provided key feedback on the prioritization of the sub-fields, which were a pre-requisite to identify the call topics, another participatory approach based on the Call Programs Consultation Committees executed the steps to prepare the call documents. The more operational, "implementation" phase of the governance process continued from here on. 
Kilkiş S.: Motors of Change Framework for R\&D and Innovation Planning towards...

Call Programs Consultation Committees: Call Programs Consultation Committees are participatory bodies that form recommendations for annual call programs. These Committees are composed of experts in the sub-field that is identified to have priority. Their main responsibility is determining the expected targets of each call, identifying the expected structure of the consortium, and reaching consensus on other points of interest, such as the project budget and duration limits. The Committees are also able to make recommendations for the panel experts who are in the best position to evaluate the applications and are responsible for evaluating the progress that is made in the call-based projects and bringing suggestions on the next calls.

The first three Consultation Committees closely followed the results of the High-level Prioritization Meeting for Energy. Two committees were formed in coal and coal technologies and solar energy (sub-fields that received top priority). The third committee was formed in energy storage based on the consensus to include this sub-topic in the first batch of calls to complement solar energy. The separate priority area of automotive also had a crosscutting nature with energy efficiency in transport, namely hybrid and electric vehicle technologies. At least four of the first ever such Committees within the priority areas of UBTYS 2011-2016, including the areas of food, automotive, ICT as well as machinery and manufacturing, involved the energy sector.

Based on the Committees' recommendations, TÜBITAK decided to launch 11 energy calls in the first batch of calls in the first year of implementation with 6 in coal technologies, 2 in solar energy, and 3 in energy storage. There were also 2 calls for hybrid and electrical vehicle technologies within the automotive calls and 1 on energy crops for biofuels in the food calls (TÜBITAK, 2011).

By the end of 2012, there were a total of 29 active calls in the priority areas of UBTYS 2011-2016. Taking into account both the sheer magnitude and level of expertise that is needed to manage the call agendas, it can be said that the Consultation Committees are a key element in the implementation phase of the governance process, including within the process for sustainable energy.

\subsection{The National Energy R\&D and Innovation Strategy}

The governance process behind the scenes of the Strategy's preparation and implementation required the timely balancing of parallel phases and steps. This was all the more evident given that different steps were linked to one another in order to provide the necessary feedback. On the part of TÜBITAK, this meant the coordination of a more challenging process with multiple dimensions, which needed to fit together both in time and content. The result was the National Energy R\&D and Innovation Strategy (TÜBITAK, 2011). The Strategy will now be overviewed based on its vision, aims, and action plans. 
Kilkiş S.: Motors of Change Framework for R\&D and Innovation Planning towards...

Vision: The vision is "to utilize energy resources effectively and efficiently without compromising environmental quality and welfare based on the knowledge and innovative products that are produced in the field of energy technologies." This vision is important for sustainable development in at least two ways. First, it emphasizes a key linkage between a better usage of energy resources and environmental quality and welfare. This relation is a key aspect of decoupling economic growth from environmental pressures. It requires lowering the energy intensity of the economy without compromising human welfare. It also requires increasing the usage of local, renewable energy resources. Second, sustainable development requires the pursuit of R\&D and innovation not only for the needs of today but also for the needs of tomorrow. The vision provides a vital direction for the energy ecosystem in Turkey.

Strategic Framework of the Strategy: To achieve this vision, the Strategy is structured upon four strategic aims. As depicted in Figure 3, the "buzzwords" of the strategic aims are namely mission-oriented R\&D projects, capacity advancement, commercialization and cooperation, and an all-encompassing governance dimension. Within the strategic framework, each of the strategic aims is then supported by their respective strategies and action plans.

Figure 3. Strategic Framework of the National Energy R\&D and Innovation Strategy (TÜBITAK, 2011)

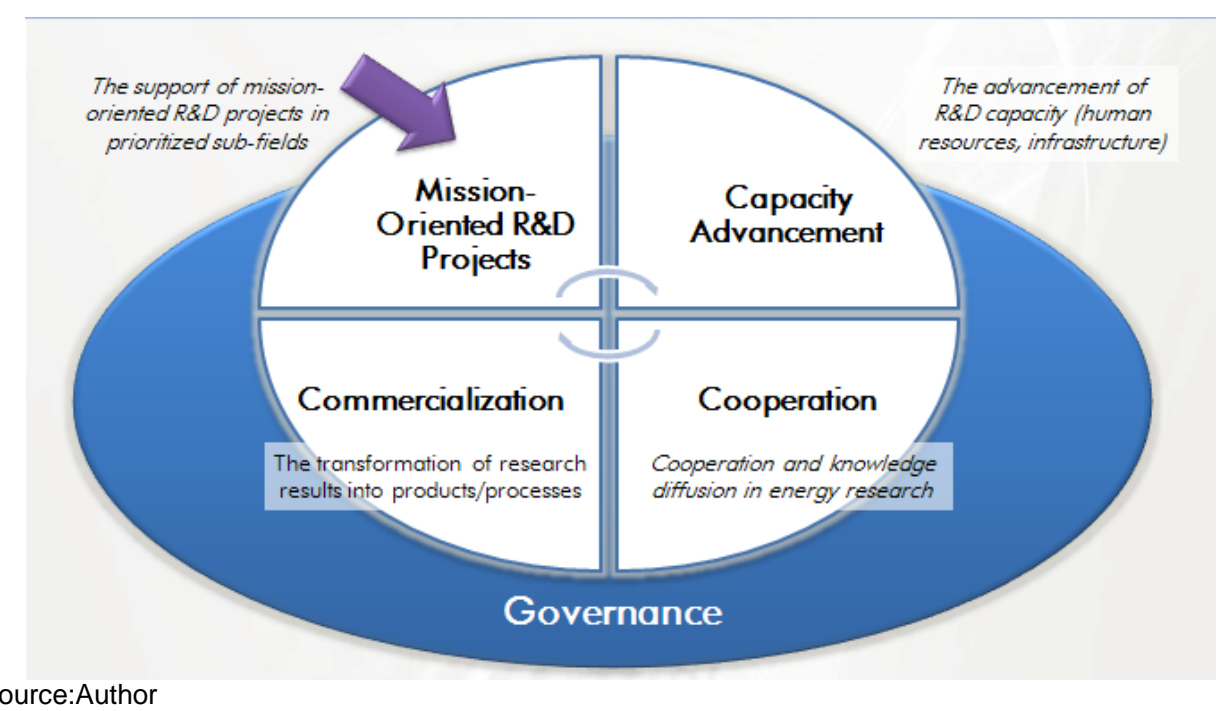

- Mission-Oriented R\&D Projects: A central aim concerns the support of call-based R\&D projects in the energy field to address national needs. It requires determining prioritized research topics and providing financial 
Kilkiş S.: Motors of Change Framework for R\&D and Innovation Planning towards...

support. Its action plan regards the formation of participatory expert groups to make the necessary decision for the prioritization and target formulations (as overviewed in the above section). It then includes the launch of project calls, the formation of a project inventory, and the organization of meetings with project leaders at least once a year to evaluate the progress being made. A second strategy is to increase international cooperation in energy since it is also possible to take part in mission-oriented approaches at this level. Related actions include the launch of bilateral and multilateral cooperation programs.

- Capacity Advancement: The second strategic aim is based on the reality that all mission-oriented approaches need a solid basis of support from research infrastructure, including human resources. The first strategy under this aim concerns the development of human resources in the energy field. The related action items include the provision of research and education scholarships, the diffusion of new undergraduate and graduate programs, and the development of a more energy-oriented curriculum in technical schools to increase supportive R\&D personnel. The second strategy regards the development of research infrastructure in the energy field. The action plan calls for the increased support of advanced thematic research centers.

- Commercialization and Cooperation: Regardless of the level of R\&D expenditures in light of the previous two strategic aims, a complementary policy is required to transform these results into greater societal benefit. The third strategic aim is put forth as the promotion of commercialization for the effective diffusion and utilization of the research results. The strategies include increasing access to knowledge of research results, the development of mechanisms to increase university-industry interaction and cooperation, and to promote inter-sectoral collaboration within call-based projects.

- Governance: All of the above strategic aims can be possible only if there is a well coordinated governance dimension. The fourth strategic aim concerns the need for effective governance mechanisms. The first strategy under this aim calls for the development of call-based public procurement schemes. The second strategy regards the active participation in international governance mechanisms. Last but not least, the third strategy is based on the measure of improving the legal framework for the support of R\&D and innovation in the energy sector. This includes making the necessary revisions in laws and directives and the utilization of public procurement to support lead markets.

It is possible to see how "governance" is extended into a broader innovation dimension as sparked by strategic aims, strategies, and action items. Next, the paper summarizes the key grant mechanism that makes possible the implementation phase of the governance process, TÜBITAK 1003 and 1511. 
Kilkiş S.: Motors of Change Framework for R\&D and Innovation Planning towards...

\subsection{Overview of the New, Call-based Grant Programs}

The design of call-based grant programs represented a shift from the topic neutral, merit-based grant schemes of TÜBITAK. This shift was triggered by the priority areas in UBTYS 2011-2016. The first of its kind, call-based grant program schemes seek to direct the innovation system actors towards carrying out mission-oriented, R\&D and innovation projects. The calls specify the objectives, targets, budget limits, and if applicable, the expected composition of project partners. Both are based on two-stage applications.

TÜBITAK 1003 Grant Program: The program coded TÜBITAK 1003 is the "Prioritized Areas R\&D Projects Grant Program (TÜBITAK, 2012-b)." Unless stated otherwise in the calls, it is possible to submit small, medium, or largescaled project applications. These scales are determined by the upper bounds of the project budgets and other characteristics, such as the project duration and expected partner compositions (e.g. university-industry collaboration).

TÜBITAK 1511 Grant Program: The program coded TÜBITAK 1511 is the "Prioritized Areas Research, Technology Development and Innovation Projects Grant Program (TÜBITAK, 2012-c)." This program does not directly characterize projects by scale. Instead, upper bounds for the project budget and other characteristics, such as project duration and expected partner compositions, are announced within each call separately. This allows for greater flexibility to account for sectoral differences and the breadth of the call topics. It is expected that the private sector leads all TÜBITAK 1511 projects.

Overview of the first batch of energy calls: Based on the schemes as described above, the TÜBITAK 1003 and 1511 Programs provide a common mechanism to direct system actors to carry out projects in priority topics. To give an idea, the first batch of 11 calls in energy is overviewed below:

- Clean coal technologies: TÜBITAK 1003 launched its first calls on clean coal technologies (TÜBITAK, 2012-d). The first of these calls regarded the upscaling of technologies for coal-drying and coal desulfurization with minimum energy and water input. The second call involved efficient coal combustion technologies, such as advanced circulating fluidized bed technologies. The third call targeted the development of coal gasification technologies, possibly with co-firing with biogas, for usage in cogeneration and integrated gasification combined cycle plants and/or co-producing liquid fuel production for transport. Three counterpart calls are also launched within TÜBITAK 1511 so that complementary technologies are developed at the same time.

- Solar energy technologies: The TÜBITAK 1511 Program opened its first calls for making the most of solar energy with more efficient solar energy technologies. The first call regarded the integration and development of mechatronic systems that effectively convert solar energy into electrical 
Kilkiş S.: Motors of Change Framework for R\&D and Innovation Planning towards...

and/or thermal energy. The second call was for the development of surfaces to increase electrical and/or thermal conversion efficiencies of solar energy.

- Energy storage technologies: Alongside calls for solar energy technologies, TÜBITAK 1511 had three calls for energy storage technologies. The first call concerned the development of mobile, new generation batteries and battery materials. The second call targeted low-cost batteries and materials with high energy and power densities for supporting the electricity grid. The third call involved battery control systems and integration for off-grid applications.

As evident from the above summaries, the different calls within the same subfield and at times, between sub-fields (i.e. solar energy and energy storage technologies) aim to produce project clusters that have the potential to merge together in the future. Another example may be given as the two calls that have been launched in the automotive sector on hybrid and electric vehicles. While these focus on regenerative breaking systems for hybrid vehicles and control algorithms for electric vehicle simulation models, it is envisioned that the third call on energy storage technologies will eventually aid this project cluster, too. For this to take place, in addition to portfolio management, the implementation bylaws of the programs indicate that meetings with the project leaders and other stakeholders will be organized at least once a year.

\subsection{R\&D and Innovative Driven "Motor of Change" for Energy}

The challenge that has been undertaken by the Strategy is neither a challenge that can be easily attained, nor a challenge that can be satisfied by a small group of actors. It requires the intense effort of all of the R\&D and innovation actors in the energy sector, including funding and coordinating bodies, such as TÜBITAK. In fact, this challenge may be characterized as the grand challenge of putting into place an R\&D and innovation driven motor of change in the energy sector towards a more sustainable development.

Figure 4 depicts the current status of the "Science and Technology Push Motor" for the field of energy in Turkey. As seen from this figure (trigger point 1), participatory approaches, such as the High-Level Prioritization Meeting for Energy and the Call Programs Consultation Committees, have been key in identifying the priorities and launching the calls, respectively. The TÜBITAK 1003 and 1511 Programs have also financed the first projects under the energy calls (trigger point 2). These two trigger points are expected to give impetus to mission-oriented R\&D projects and give feedback to the system.

The integration of top-down and bottom-up approaches were important from a motor of change perspective. Since "guidance of search and selection" (F4) cannot be seen in isolation of the other necessary functions, top-down and bottom-up approaches must be integrated from the very beginning for the successful working of the motor as a whole in the future (see trigger point 1 in 
Kilkiş S.: Motors of Change Framework for R\&D and Innovation Planning towards...

Figure 4). As a result, F4 must be satisfied taking into consideration that R\&D performers and the actors of the innovation system need to be involved in the decision-making process since they will be the ones who will be responsible for the performance of the system in the following activities. In reference to Table 1, after the initial trigger of F4, there should also be a mobilization of researchers and call-based funding as F6 (trigger point 4 in Figure 4) as well as knowledge development (F2) and knowledge diffusion (F3).

Figure 4. Mission-Oriented Approaches towards Activating Motors of Change

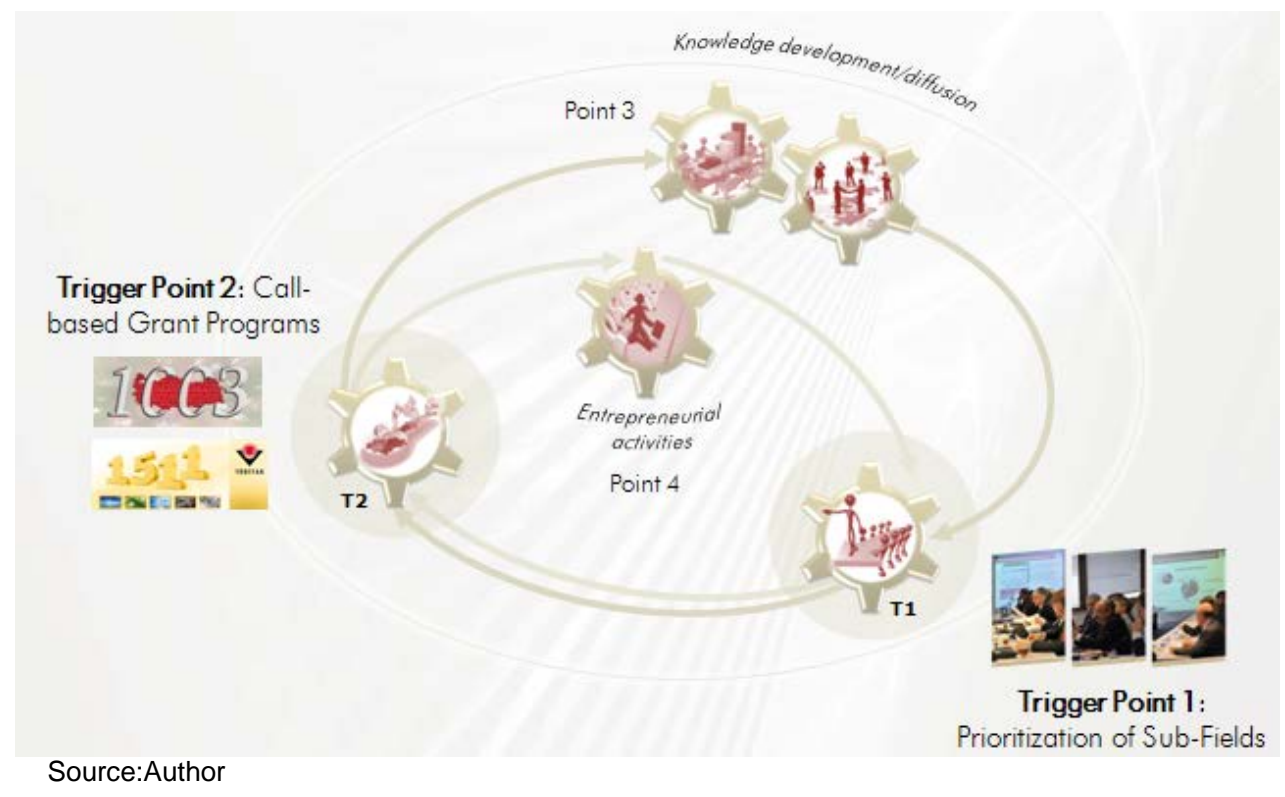

The next challenge comes in ensuring that the call programs are kept up-todate according to the emerging trends, pressing needs, and recent progress of the sector. Meeting this challenge is also necessary to provide feedback into the call programs (point 3). Such dynamics as "experimentation and learning" may remain weak in the first motor in general (point 4). When strengthened, it may trigger the next motor, namely the "Entrepreneurial Motor" (see Table 1). Therefore, the next challenge in the management of the mission-oriented approach is to sustain the "motor of change" that is activated in Turkey. For this reason, the process that is designed for the initial launch of M1 should also be repeated when sufficient progress is made in the level of maturity of the system to proceed to M2. It may also be possible to skip to M3. The determining factor is the results of the calls that have been opened and the number of successful technologies that are developed as a result. 
Kilkiş S.: Motors of Change Framework for R\&D and Innovation Planning towards...

Ultimately, the effective activation of "motors of change" has the potential to bring in key socio-economic and environmental benefits to the country. Other "motors" include the "System Building Motor" and the "Market Motor." As the third and fourth motors, these serve the target of fully scaling-up successful product niches and attaining a more mature, self-sustaining stage for a given technology to compete with incumbent technologies. In Kılkış (2012), a proposal is given regarding the sequencing and transition of different motors.

At the same time, call programs need a systematic, technology road-map context to have a better impact in the innovation system. A new participatory approach will be added for a supporting technology-roadmapping process. This process will also identify any bottlenecks as they arise as an early warning system. For the second year, the topic of "Energy Efficiency" is selected for a pilot technology roadmap process. Through a new sectoral, multi-actor governance process that can provide the correct inputs (e.g. foresight, bottlenecks), it is foreseen that it will be possible to make timely decisions to manage developments to raise benefits for sustainable energy.

\subsection{Sustainable Energy Expectations}

Before casting more forward-looking expectations for the future, it is useful to take a look at the present state of energy production and utilization in Turkey. Presently, the self-sufficiency ratio for Turkey, which is defined as energy production from local energy resources (32.5 Mtoe) divided by the primary energy supply (109.3 Mtoe), is $29.7 \%$. On the energy end-usage side, the final energy consumption of 83.4 Mtoe is shared among the industry (37\%), building (34\%), transport (19\%), and other (10\%) sectors (Ministry of Energy).

At the energy policy level, the Energy Efficiency Strategy Document 20122023 as adopted by the High Planning Council (YPK) puts forth the target of reducing the energy intensity of the economy by at least $20 \%$ by the year 2023 based on 2011 values (YPK, 2009). This requires reducing the energy being spent on an annual basis across all sectors for each unit of GDP produced. Measures that conserve and utilize energy more rationally without compromising the functioning of societal tasks or the quality of life are needed. The Strategy Document for the Security of Supply puts forth the target that the share of renewable energy sources in total electricity production shall be kept to be at least 30\% by the year 2023 (YPK, 2009). The same document provides targets to utilize the energy potentials of wind, solar, and geothermal energy more effectively. Finally, the revised Renewable Energy Law raises the feed-in tariff for renewable energy (Law 6094, 2011). 
Kilkiş S.: Motors of Change Framework for R\&D and Innovation Planning towards...

\section{Conclusion}

This paper has analyzed the process of activating the national R\&D and innovation actors in the area of energy technologies in Turkey. The milestones of this governance process include a multitude of participatory approaches for strategy-building, prioritization, and implementation. These included a stakeholder workshop, working group meetings, and focus groups that involved a broad range of energy stakeholders in Turkey. These mediums were designed so that each approach provided inputs to the next in a cascaded approach, including those from a High-Level Prioritization Meeting.

The Strategy includes mission-oriented R\&D projects, capacity advancement, commercialization and cooperation, and governance. Within the missionoriented R\&D projects, the call-based TÜBITAK 1003 and 1511 Programs have been used to steer existing TÜBITAK R\&D grant programs from more neutral funding approaches to directly mission-oriented approaches for the first time. As a result, the first calls that have been launched by TÜBITAK represent a "giant step" for the R\&D and innovation ecosystem in Turkey. The topics of the first 11 energy calls have been highlighted, which include calls on clean coal technologies, solar energy, and energy storage technologies.

The paper has further identified the next challenges in the management of mission-oriented approaches to sustain "motors of change" in the energy sector. After the calls start producing R\&D results, other participatory approaches, such as concertation meetings, can be utilized in advancing to other system building motors. Finally, present energy statistics and renewable energy targets were provided as the starting point from which to move forward and create positive change for the future. It is concluded that the governance of R\&D and innovation towards sustainable energy will lead to key socioeconomic and environmental benefits for a better sustainable development.

The launch of a motor of change, especially in an R\&D and innovation landscape where a more mission-oriented approach will be implemented for the first time, is an intense process. First, it requires intense effort to identify the priorities that is expected to have the most impact in the long run based on R\&D and innovation efforts. Second, it requires coordination so that the priorities that are identified can be translated into focused research efforts, mainly through the launch of call-based funding. In the case of Turkey, this process was managed based on a methodology that integrated motors of change concepts to transform the system into a mission-oriented system through the use of both bottom-up and top-down approaches. The research question is fulfilled with a unique case study contribution to the literature. 
Kilkiş S.: Motors of Change Framework for R\&D and Innovation Planning towards...

\section{References}

Bergek, A. et al. (2008). Analyzing the Functional Dynamics of Technological Innovation Systems: A Scheme of Analysis. Research Policy, (37)3, 407-429.

Dick, S., Roger, J., Launius, D., Editors (2007). Societal Impact of Spaceflight. Washington D.C.: NASA.

Freeman, C. (1996). The Greening of Technology and Models of Innovation. Technological Forecasting and Social Change, (53)1, 27-39, doi:000601.

Hargroves, K., Smith, H., Editors (2006). The Natural Advantage of Nations (Vol.1): Business Opportunities, Innovation and Governance in the $21^{\text {st }}$ Century. London: Earthscan.

Hekkert, M. et al. (2007). Functions of Innovation Systems: A New Approach for Analysing Technological Change, Technological Forecasting and Social Change, (74)4, 413-432.

High Planning Council - YPK (2012). Decision No. 2012/1 Energy Efficiency Strategy 2012-2023. Ankara.

Kılkış, Ş. (2012). The Management of a Transition Process towards a Sustainable Future on the Axes of Science, Technology and Innovation: Analysis of the Strategic Framework and Proposals for our Country (Unpublished TÜBITAK Expertise Thesis). Ankara.

Kooiman, J. (1993). Modern Governance New Government-Society Interactions. London Newbury Park, California: Sage.

Law No. 6094 (2011). Renewable Energy Law. Ankara: T.C. Official Circular.

Loorbach, D. (2007). Transition Management: New Mode of Governance for Sustainable Development (PhD Thesis). Utrecht: International Books.

Morlacchi, P. (2009). Emerging Challenges for Science, Technology and Innovation Policy Research: A Reflexive Overview. Research Policy, 38(4), 571-582, doi: 01.021.

National Aeronautics and Space Administration (2009). Spin-Off: Innovative Partnership. Washington D.C.: NASA.

Rotmans, J. et al. (2000). Transitions and Transition Management: The Case of a Low-Emission Energy Supply. Maastricht: ICIS-Report.

SCST (2010). Evaluation of Developments at the $22^{\text {nd }}$ Meeting of the SCST.

Soete, L. (2010). The Role of Research and Innovation for the Knowledgebased Economy. Paper presented at the Week of Innovative Regions in Europe, Granada. Retrieved from http://ec.europa.eu/research/era/pdf/ community_research_policy_role.pdf.

Stamm, A. et al. (2009). Sustainability-Oriented Innovation Systems: Towards Decoupling Economic Growth from Environmental Pressures? Bonn: German Development Institute. 
Kilkiş S.: Motors of Change Framework for R\&D and Innovation Planning towards...

Stine, D. (2008). The Manhattan Project, the Apollo Program, and Federal Energy Technology R\&D Programs: A Comparative Analysis. CRS Report for Congress, Washington D.C.

Suurs, R. (2009). Motors of Sustainable Innovation: Towards a Theory on the Dynamics of Technological Innovation Systems (Unpublished PhD Thesis). Utrecht.

T.C. Ministry of Energy and Natural Resources (2011). Energy Balance. Retrieved from www.etkb.gov.tr.

TÜBITAK (2011). National Energy R\&D and Innovation Strategy, Annex to Decree No. 2010/101 at the $23^{\text {rd }}$ Meeting of the SCST, Ankara.

TÜBITAK (2012-a). High-Level Prioritization Group Meeting of the Energy Sector. Retrieved from http://www.tubitak.gov.tr/sid/2402/pid/2400/cid/ 27559/index.htm.

TÜBITAK (2012-b). Implementation Bylaws of the TÜBITAK 1003 Program.

TÜBITAK (2012-c). Implementation Bylaws of the TÜBiTAK 1511 Program.

TÜBITAK (2012-d). Calls of the TÜBITAK 1003/1511 Programs. Retrieved from http://www.tubitak.gov.tr/.

Turkish Statistical Institute (2011). Foreign Trade Statistics. Retrieved from www.tuik.gov.tr.

YPK (2009). Decision No. 2009/11 Electrical Energy Market and Security of Supply Strategy. Ankara. 